\title{
Zastosowanie klejowych materiałów regeneracyjnych do napraw instalacji rurowych
}

\author{
Application of adhesive regenerative materials \\ to pipe systems repair
}

\section{Streszczenie}

W artykule scharakteryzowano adhezyjne materiały regeneracyjne, ze szczególnym zwróceniem uwagi na taśmy naprawcze. Dla próbek w kształcie rur z wywierconymi otworami o średnicy 10 i $20 \mathrm{~mm}$ analizowano rozkłady naprężeń metodą elementów skończonych. Eksperyment przeprowadzono bazując na wytycznych PN-EN ISO 24817:2015-10. Dla trzech wybranych rozwiązań naprawczych: taśmy zbrojonej, taśmy uszczelniającej i dedykowanego systemu naprawczego przeprowadzono próby ciśnieniowe. Opisano wyniki badań i potencjał aplikacyjny stosowanych rozwiązań.

Słowa kluczowe: technologia klejenia; materiały regeneracyjne; taśmy naprawcze; instalacje rurowe

\begin{abstract}
In this article, adhesive regenerative materials were characterized, with special attention paid to repair tapes. For pipe-shaped specimens with bore holes of 10 and $20 \mathrm{~mm}$ diameter, stress distribution was analyzed with finite element method. The experiment was conducted basing on PN-EN ISO 24817: 2015-10 guidelines. For three selected repair solutions: reinforced tape, sealing tape and dedicated repair system, pressure tests were performed. The research results and application potential of applied solutions are described.
\end{abstract}

Keywords: adhesive technology; regenerative materials; repair tapes; pipe systems

\section{Wprowadzenie - klejenie w regeneracji}

Odkrycie w latach czterdziestych XX wieku makromolekularnej budowy substancji spowodowało dynamiczny rozwój klejów syntetycznych na bazie żywic sztucznych, które wyparły spoiwa oparte na składnikach pochodzenia naturalnego. Umożliwiło to otrzymywanie połączeń o podobnych właściwościach jak w przypadku spawania, lutowania czy zgrzewania, jednak nakładem mniejszych kosztów i pracy. Klejenie stało się realną alternatywą tych technik, oferującą szereg zalet, niemożliwych do uzyskania innymi metodami. Duża różnorodność spoiw przeznaczonych do klejenia oraz wynikająca z niej możliwość uzyskiwania pełnej gamy właściwości w zależności od potrzeb, stawia tę technologię w czołówce najbardziej przyszłościowych metod spajania. Uzyskanie poprawnego połączenia klejowego wymaga uwzględnienia czynników materiałowych (struktura i właściwości klejów oraz materiałów klejonych), technologicznych (stopień przygotowania powierzchni elementów, sposób przygotowania i nanoszenia masy klejowej, warunki utwardzania spoiny klejowej), konstrukcyjnych (sposób obciążenia, geometria i symetryczność połączenia, ukształtowanie elementów złącza) oraz warunków eksploatacyjnych pracy złączy (agresywność środowiska, zakres

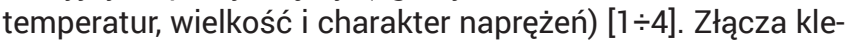
jowe, obok swojej podstawowej roli spajania elementów, często pełnią też funkcje wspomagające takie jak uszczelnianie, mocowanie czy zabezpieczanie, mogą być również wykonywane jako kombinowane $z$ innymi technikami spajania.

Rozwiązania adhezyjne zyskują coraz większą rzeszę zwolenników w zakresie napraw i regeneracji. Przemawia za tym szybkość i łatwość wykonania, zasadność ekonomiczna oraz coraz częściej skuteczność takiej aplikacji. Wbrew utrwalanym stereotypom podważającym funkcjonalność rozwiązań klejowych, intensywny rozwój tych technik spowodował, że stały się one alternatywą technologii termicznych, często nie ustępując im pod względem jakości oraz wytrzymałości mechanicznej złączy. Aktualnie klejenie z powodzeniem stosowane jest w naprawach elementów metalowych i niemetalowych, pozwalając uzyskać jakościowe, szczelne połączenie, bez wprowadzania dodatkowych naprężeń. Niezależnie od wyboru klejowej metody regeneracji

Dr inż. Tomasz Piwowarczyk, inż. Marcin Judziński - Politechnika Wrocławska, mgr inż. Wojciech Kozak - Henkel Polska Sp. z o.o.

Autor korespondencyjny/Corresponding author. tomasz.piwowarczyk@pwr.edu.pl 
istotne jest, aby powierzchnia naprawiana była przygotowana w odpowiedni sposób. Metody przygotowania powierzchni elementów do procesu klejenia powinny zapewniać osiąganie najkorzystniejszych właściwości połączeń adhezyjnych, uwzględniając rodzaj materiałów łączonych

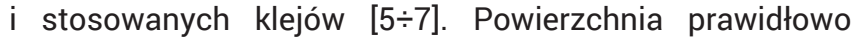
przygotowana do procesu klejenia charakteryzuje się brakiem zanieczyszczeń redukujących adhezję, rozwinięciem powierzchni (optymalnie: obróbka strumieniowo-ścierna) dobrą zwilżalnością klejem, zdolnością do wytwarzania wiązań międzyfazowych, stabilnością dla założonych warunków i czasu eksploatacji złącza, powtarzalnością uzyskiwanych właściwości, obecnością podkładów lub aktywatorów (jeśli są wymagane) $[8 \div 10]$.

Spośród licznych adhezyjnych materiałów regeneracyjnych do najpopularniejszych należą $[3,11]$ : pasty i płyny gumopodobne (zwykle dwuskładnikowe materiały na bazie uretanów, składające się z bazy oraz katalizatora, cechujące się elastycznością, antykorozyjnością, dobrymi właściwościami ściernymi, odpornością na rozciąganie oraz działanie substancji chemicznych), silikony (jednoskładnikowe produkty utwardzające się poprzez pobieranie wilgoci z powietrza, wykazujące dużą elastyczność oraz niekiedy szerokie spektrum odporności chemicznej i temperaturowej), kompozyty (głównie na bazie żywicy epoksydowej z napełniaczami chemicznie obojętnymi, np. mączka drzewna, kaolin, lub wzmacniającymi np. proszki metali, proszki ceramiczne, krzemiany, materiały włókniste; nazywane często „zimnymi metalami"), taśmy naprawcze oraz grupa rozwiązań dedykowanych pod konkretne zastosowania. W grupie taśm naprawczych należy dodatkowo wyróżnić: taśmy silikonowe samowiążące, taśmy zbrojone (wykonywane zwykle z folii polipropylenowej zbrojonej np. włóknem szklanym wzdłużnie lub/i poprzecznie), taśmy wzmacniające (najczęściej w formie siatki z włókna szklanego lub węglowego) oraz specjalistyczne taśmy uszczelniające.

Z praktycznego punktu widzenia, szczególnie ciekawe wydaje się zastosowanie spoiw adhezyjnych do regeneracji elementów rurowych. Potencjał aplikacyjny różnego rodzaju instalacji jest znaczny, co w połączeniu ze zmiennym stopniem zaawansowania technologicznego i konstrukcyjnego takich systemów powoduje, że zapotrzebowanie na adhezyjne rozwiązania naprawcze jest duże. Aktualnie na rynku istnieje wiele metod regeneracji elementów rurowych, a ich stopień skomplikowania i obszar zastosowania jest znacząco różny. Wybór rozwiązania powinien być podyktowany charakterem eksploatacji, ciśnieniem panującym wewnątrz instalacji, rodzajem przenoszonego medium, zakresem występujących temperatur oraz szybkością ich zmian, wymiarami przekroju poprzecznego i typem potencjalnego uszkodzenia. Konieczność uzyskiwania trwałych efektów napraw, przy minimalizacji kosztów i zmniejszaniu czasów oraz stopnia ingerencji w instalację rurową (brak obciążeń cieplnych wprowadzających dodatkowe naprężenia), zmusza producentów do zaproponowania rozwiązań kompleksowych dla zastosowań szczególnych.

\section{Przygotowanie próbek i metodyka badań}

Potencjał zastosowania klejowych materiałów regeneracyjnych do napraw instalacji rurowych został określony bazując na wytycznych normy PN-EN ISO 24817:2015-10 „Przemysł naftowy, petrochemiczny i gazowniczy. Kompozytowe środki do naprawy rur. Kwalifikacja oraz projektowanie, instalowanie, badanie i kontrola", która opisuje podstawowe problemy związane naprawami, definiując typ uszkodzeń, spektrum zastosowań, rodzaj napraw oraz ich żywotność, a także wspomaga projektowanie i weryfikowanie systemów naprawczych.

Z rury o grubości ścianki $4 \mathrm{~mm}$ i średnicy $75 \mathrm{~mm}$ wycięto odcinki o długości $600 \mathrm{~mm}$, a następnie wyznaczono środki długości rur, w których wywiercono otwory o średnicy $10 \mathrm{~mm}$ oraz $20 \mathrm{~mm}$. W celu zaślepienia rur oraz stabilnego ich ułożenia podczas wykonywania doświadczenia na ich końcach dospawano płaskowniki stalowe o wymiarach 100x100x10 mm. W każdym płaskowniku wytrasowano środek, w którym wywiercono otwór o średnicy $12 \mathrm{~mm}$ pod króciec łączący z praską hydrauliczną. Kształt i wymiary próbek przygotowanych do badań pokazano na rysunku 1.

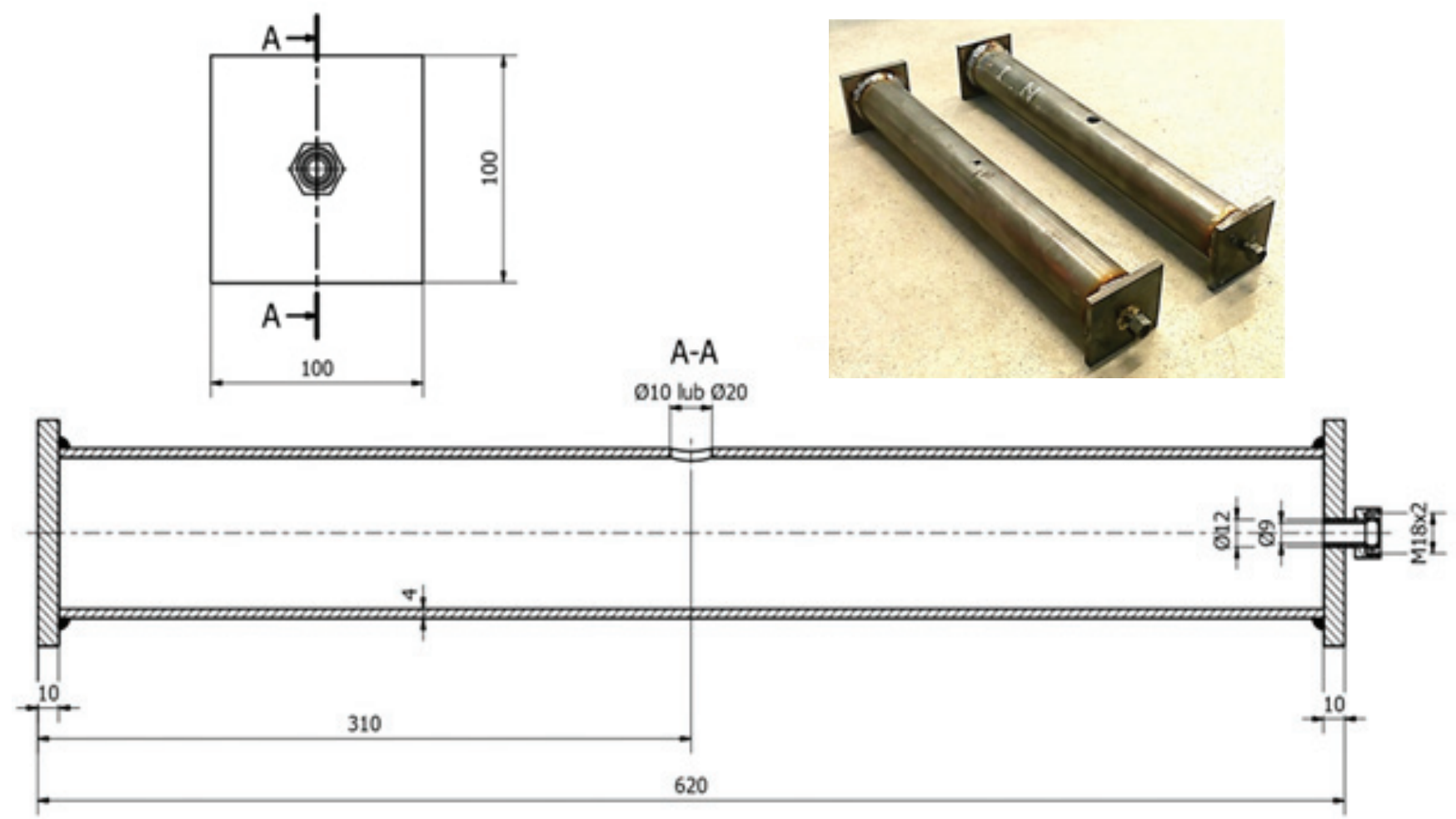

Rys. 1. Kształt i wymiary próbek przygotowanych do badań

Fig. 1. Shape and dimensions of samples prepared for testing 
Schemat układu pomiarowego został przedstawiony na rysunku 2. Próby wykonano z wykorzystaniem hydraulicznej praski manometrycznej (1), która wtłacza olej ze zbiornika (2) do układu, poprzez elastyczne przewody hydrauliczne (4). Manometryczna praska hydrauliczna (1) sterowana jest ręcznie, za pomocą śruby (3), która zwiększa ciśnienie w układzie podczas jej dokręcania. Ciśnienie panujące w rurze (6) można zaobserwować na podłączonym do układu manometrze (5) o działce elementarnej 0,02 MPa oraz zakresie wskazań wynoszącym od 0 do $25 \mathrm{MPa}$. Rura (6) została umieszczona w izolowanym zbiorniku (7) w celu zachowania zasad bezpieczeństwa oraz higieny pracy.

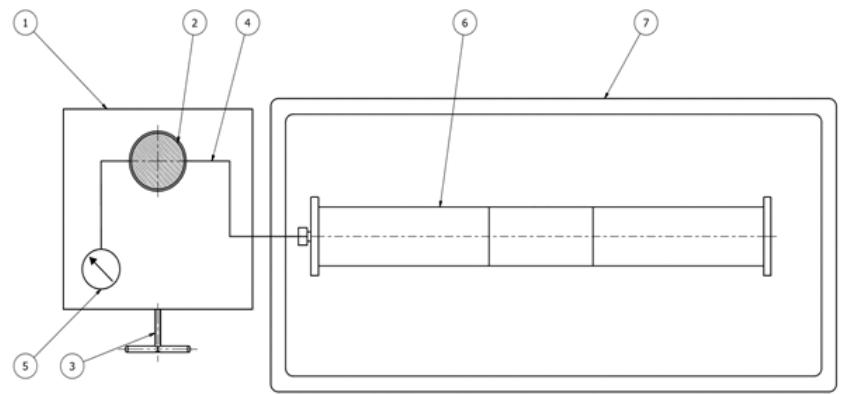

Rys. 2. Schemat stanowiska pomiarowego Fig. 2. Scheme of measurement stand

Eksperyment przeprowadzono porównawczo dla trzech systemów naprawczych: taśmy zbrojonej włóknem szklanym, specjalistycznej taśmy uszczelniającej i certyfikowanego (wg ISO 24817) systemu naprawczego Loctite. Badanie wykonanej naprawy polegało na wyznaczeniu ciśnienia granicznego w rurze, podczas którego system naprawczy ulegał uszkodzeniu (dochodziło do utraty szczelności układu). Dla każdej metody naprawczej powierzchnia rury została przygotowana w taki sposób, aby uzyskać jak najlepsze właściwości adhezyjne taśmy do rury.

\section{Analiza MES rozkładu naprężeń w rurze}

W celu poznania rzeczywistego rozkładu naprężeń w rurze przed naprawą przeprowadzono analizę metodą elementów skończonych (MES). Kształt przygotowanych próbek zamodelowano za pomocą oprogramowania CAD, wykorzystując ich symetrię. Modele zaimplementowano do programu MES, nadając im właściwości niestopowej stali konstrukcyjnej (S235JR). Podczas nadawania wiązań zablokowano ruch powierzchni powstałych wskutek przecięcia modelu, w kierunku do nich prostopadłym. Analizę MES przeprowadzono dla ciśnienia wynoszącego $5 \mathrm{MPa}$, które odpowiada wartości, dla której certyfikowane są systemy naprawcze zgodne z normą. Ciśnienie przyłożone zostało do powierzchni wewnętrznych modeli, zgodnie $z$ jego rzeczywistym oddziaływaniem. Ze względu na występujący w obu modelach otwór należało $w$ ich miejscu umieścić siłę zastępczą, o kierunku i zwrocie zgodnym z panującym w układzie ciśnieniu. Wyniki obliczeń naprężeń Misesa-Hubera dla próbki z otworem o średnicy $10 \mathrm{~mm}$ przedstawiono na rysunku 3 , natomiast dla próbki z otworem o średnicy $20 \mathrm{~mm}$ na rysunku 4. Analizy zobrazowały rozkład naprężeń dla założonych warunków konstrukcyjnych. Pozwala to szacować naprężenia panujące w układzie przed naprawą i na tej podstawie dobór materiału regeneracyjnego i ilości warstw taśmy zabezpieczającej.

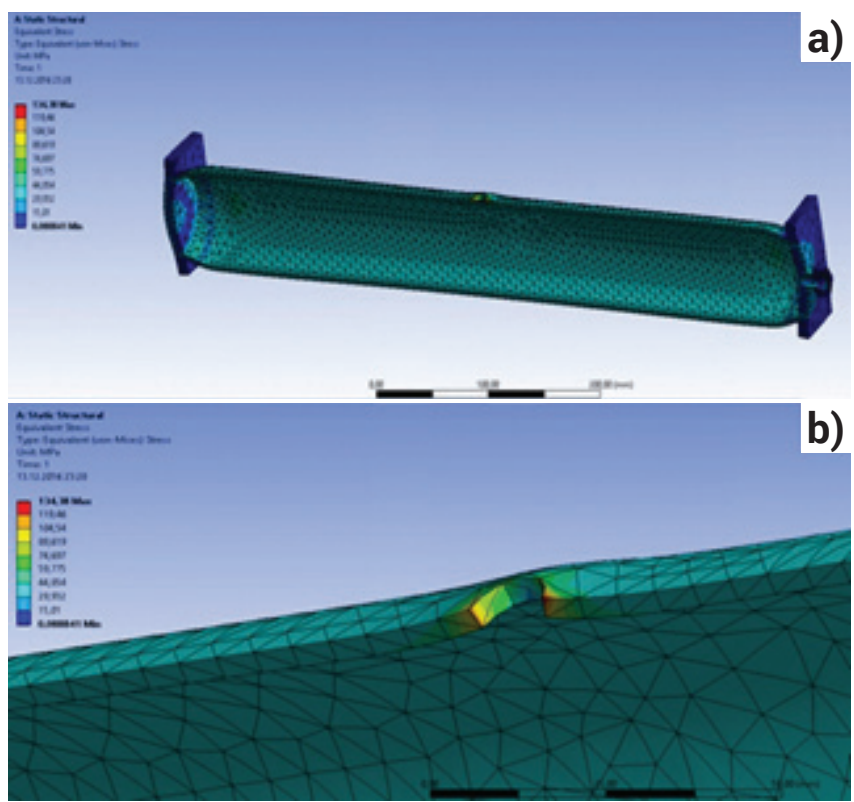

Rys. 3. Rozkład naprężeń Misesa-Hubera dla rury z otworem o średnicy $10 \mathrm{~mm}$

Fig. 3. Mises-Huber stress distribution for pipe with $10 \mathrm{~mm}$ diameter hole

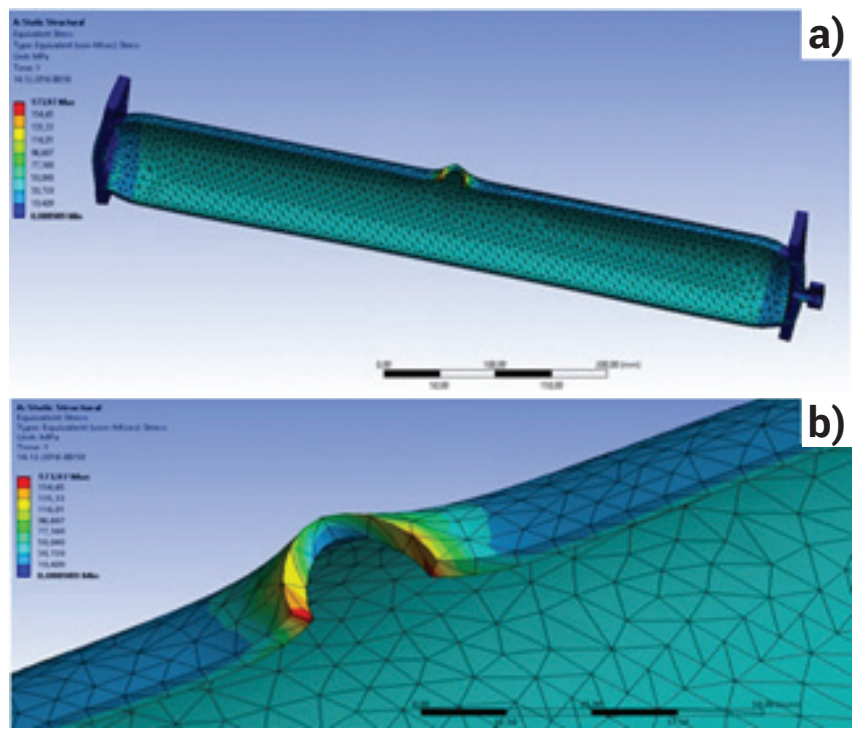

Rys. 4. Rozkład naprężeń Misesa-Hubera dla rury z otworem o średnicy $20 \mathrm{~mm}$

Fig. 4. Mises-Huber stress distribution for pipe with $20 \mathrm{~mm}$ diameter hole

\section{Regeneracja $z$ wykorzystaniem taśmy zbrojonej oraz uszczelniającej}

Przed przystąpieniem do naprawy rury zostały oczyszczone, a następnie ich powierzchnia została odtłuszczona w celu poprawy własności adhezyjnych podłoża. Zastosowano taśmę zbrojoną włóknem szklanym (rys. 5a) oraz w kolejnej próbie taśmę uszczelniającą (rys. 5b), obie o szerokości $50 \mathrm{~mm}$. Pierwsza warstwa taśmy owinięta została wokół rury symetrycznie względem otworu, dwie kolejne warstwy naniesione zostały na zakładkę, $10 \mathrm{~mm}$ od przeciwnych końców pasa pierwszej warstwy taśmy. Uzyskano w ten sposób złącze o łącznej szerokości ok. $70 \mathrm{~mm}$. Miejsce zakończenia każdej z warstw taśmy zostało umieszczone po przeciwnej stronie otworu. Wizualizację takiego złącza przedstawia rysunek 6 . Podczas aplikacji taśmy zadbano, by przylegała ona do rury całą swoją powierzchnią, a po nałożeniu każdej z warstw taśmę oraz rurę ponownie odtłuszczano. 
a)

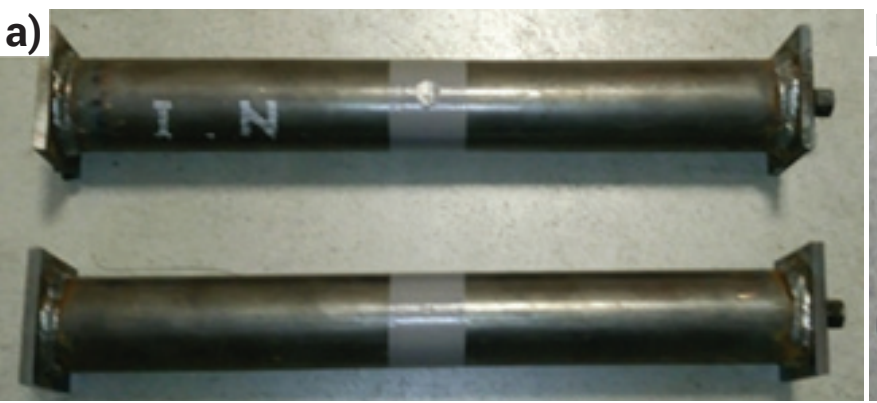

Rys. 5. Naprawa wykonana z użyciem a) taśmy zbrojonej, b) taśmy uszczelniającej

Fig. 5. Repair made with a) reinforced tape, b) sealing tape
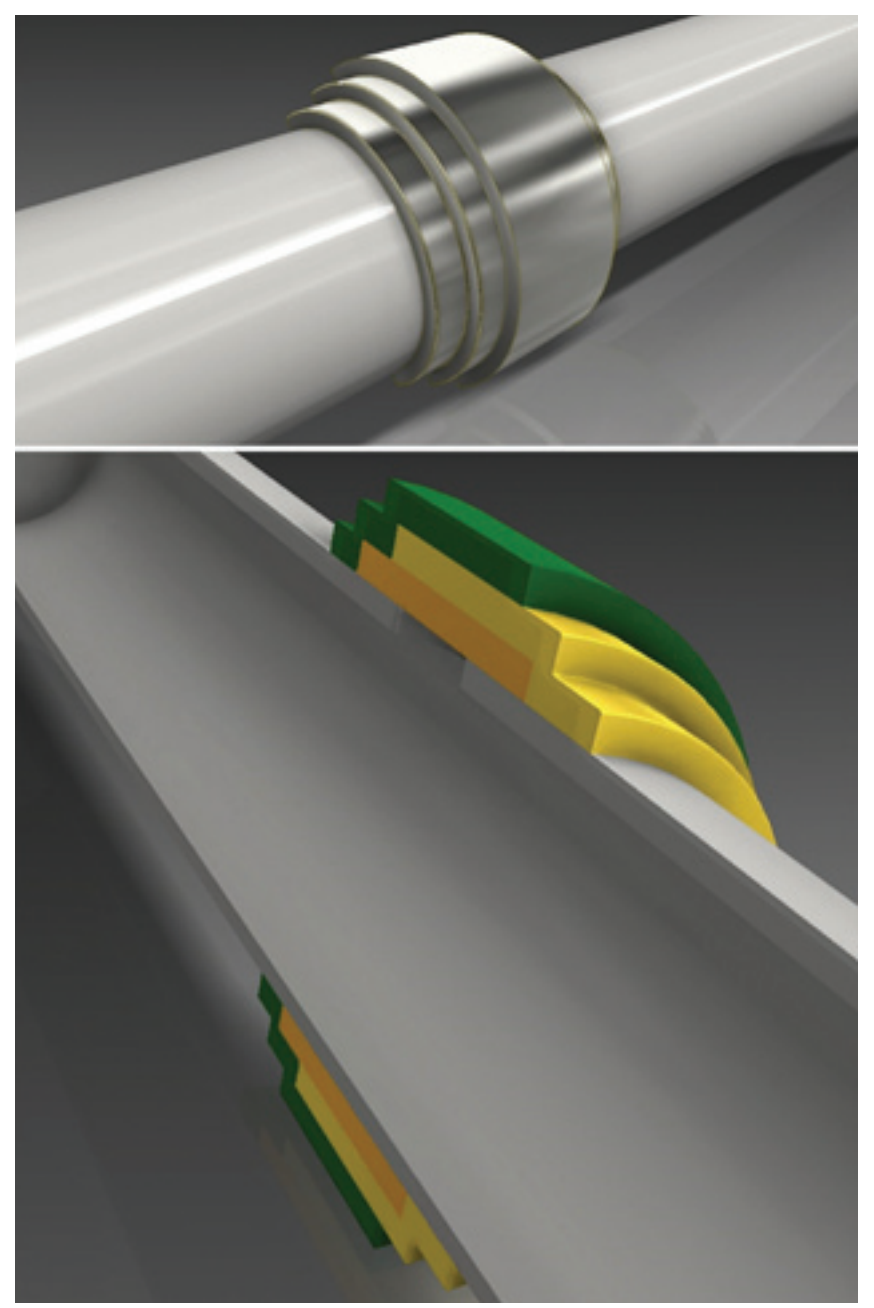

Rys. 6. Wizualizacja złącza zakładkowego

Fig. 6. Visualization of the overlap joint

\section{Regeneracja z wykorzystaniem dedyko- wanego systemu naprawczego}

Próba właściwa została wykonana z zastosowaniem certyfikowanego systemu naprawczego firmy Loctite, łączącego kompozyt regeneracyjny na bazie żywic epoksydowych z dodatkowym wzmocnieniem specjalnymi taśmami zbrojonymi. Według wytycznych PN-EN ISO 24817 system naprawczy, aby uzyskać certyfikat, musi dla 100 kolejnych prób wytrzymać ciśnienie $5 \mathrm{MPa}$ (50 barów). Rozwiązanie takie jest bardziej kosztowne od prostych metod naprawczych i wymaga wykonania operacji w odpowiedniej kolejności, jednak według zapewnień producenta osiągane rezultaty są o wiele lepsze w porównaniu z innymi metodami. Zregenerowana w ten sposób rura wytrzymuje duże ciśnienia, a deklarowana żywotność naprawy wynosi 20 lat. Można je stosować na ubytki typu $A$, tj. miejscową nieznaczną utratę nominalnej grubości ścianki, oraz typu B, czyli powstały eksploatacyjnie otwór.

Procedurę wykonania naprawy pokazano na rysunku 7. W celu uzyskania korzystnych właściwości adhezyjnych zastosowano się do zaleceń producenta - rury po odtłuszczeniu zostały poddane podciśnieniowej obróbce strumieniowo-ściernej przy użyciu białego elektrokorundu szlachetnego 99A (rys. 8a). Po procesie obróbki próbki zabezpieczono wodnym środkiem antykorozyjnym Loctite 7515. Do wykonania naprawy przygotowano dwuskładnikową żywicę epoksydową o oznaczeniu handlowym Loctite 7210 oraz taśmę wzmacniającą z włókna węglowo-szklanego Loctite 5085. Żywicę epoksydową wymieszano z utwardzaczem w proporcjach masowych 100:40. Tak przygotowaną mieszaninę nanoszono za pomocą dołączonej do zestawu szpachelki na odtłuszczone powierzchnie rur, ponad $100 \mathrm{~mm}$ od środka wywierconych otworów w każdą ze stron, tworząc warstwę żywicy epoksydowej o szerokości przekraczającej nieznacznie $200 \mathrm{~mm}$ (rys. 8b). Podczas wykonywania rzeczywistej naprawy należy się skonsultować z przedstawicielem producenta w celu wyliczenia ilości potrzebnych warstw i określenia zależności kształtowo-wymiarowych zakładki. Szerokość warstwy żywicy epoksydowej związana jest z szerokością zaprojektowanego złącza. Taśmę wzmacniającą o szerokości $120 \mathrm{~mm}$ pocięto na odcinki o długości dopasowanej do obwodu rury i nasączono wymieszaną żywicą. Nanoszenie żywicy epoksydowej na tkaninę rozpoczęto od strony włókna szklanego. Po nasączeniu pasy zostały odwrócone, aby odsłonić warstwę zbudowaną z włókna węglowego i ponownie naniesiono żywicę. Po ukończeniu aplikacji wykorzystano wałek do odpowietrzania, aby usunąć z taśmy wzmacniającej resztki powietrza i zwiększyć stopień

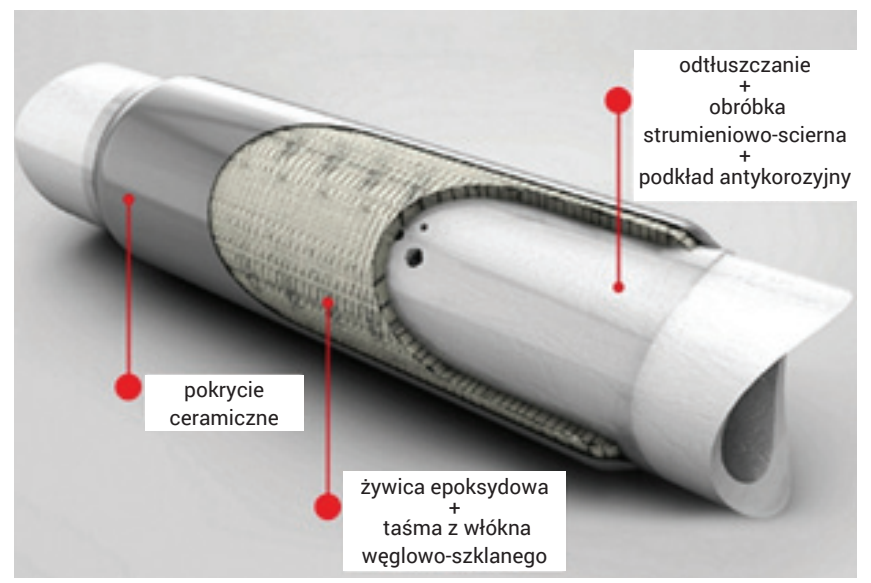

Rys. 7. Regeneracja z użyciem dedykowanego systemu naprawczego Fig. 7. Regeneration with a dedicated repair system 
nasączenia taśmy. Proces ten przeprowadzono zgodnie z zaleceniami producenta, które polegały na czterdziestokrotnym przetoczeniu dedykowanego wałka po taśmie wzmacniającej od strony, której zewnętrzną warstwę stanowi splot włókna węglowego, stosując przy tym niewielki docisk wałka. Przygotowane pasy taśmy wzmacniającej zostały naniesione na próbki w miejscach zgodnych z zaprojektowanym złączem zakładkowym. Pierwszy pas owinięty został wokół próbki symetrycznie względem otworu, a kolejne pasy nakładane były $40 \mathrm{~mm}$ od przeciwnych końców pasa środkowego, tworząc złącze o łącznej szerokości ok. $200 \mathrm{~mm}$. Każdy z pasów nakładany był warstwą z włókna szklanego do powierzchni rury, a podczas nakładania dociskany był przy pomocy wałka do odpowietrzania, aby zapewnić jak największą powierzchnię przylegania (rys. 8c). Próbki utwardzano w temperaturze pokojowej do uzyskania pełnej polimeryzacji. Producent zaleca zabezpieczyć złącze specjalnym sprayem ceramicznym Loctite 7255 , w celu poprawy jego odporności i wydłużenia żywotności, jednak na potrzeby eksperymentu nie zastosowano tego etapu. Przypadki napraw trudniejszych rozwiązań konstrukcyjnych instalacji pokazano na rysunku 9.
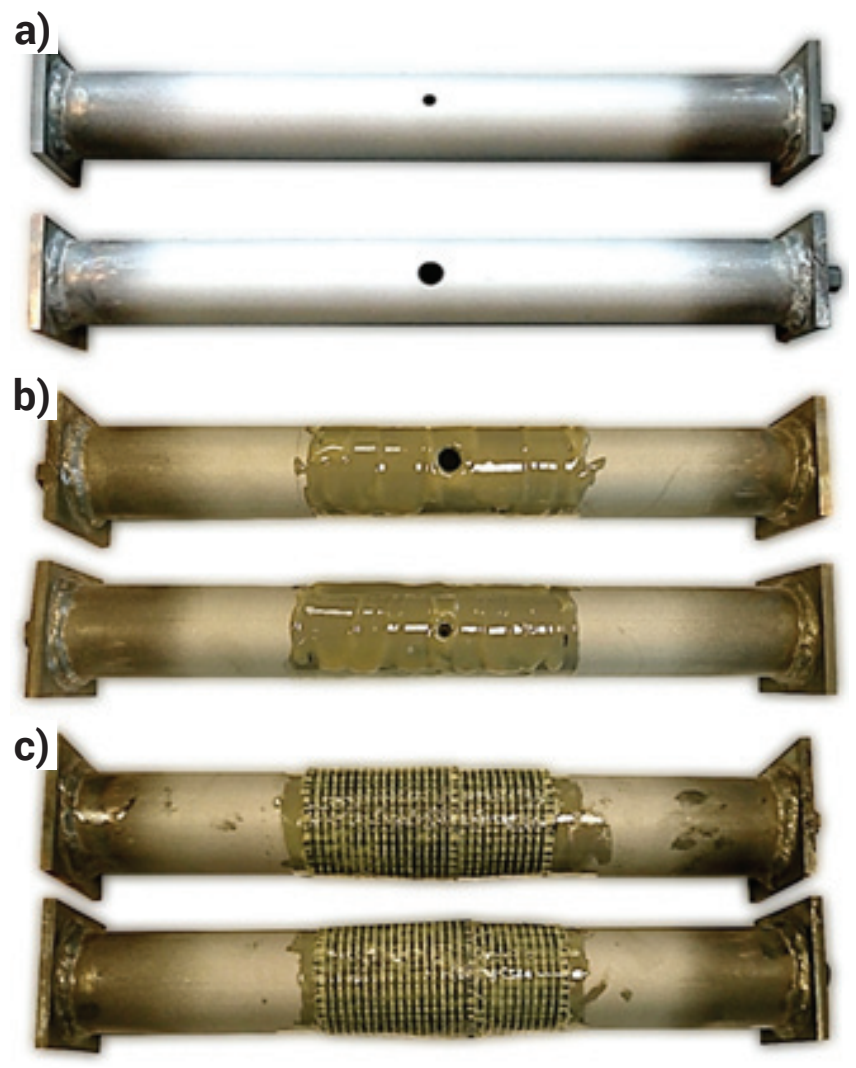

Rys. 8. Etapy regeneracji z użyciem dedykowanego systemu naprawczego: a) rury po obróbce strumieniowo-ściernej, b) aplikacja żywicy, c) elementy bezpośrednio po naprawie

Fig. 8. Stages of regeneration with use of dedicated repair system: a) tubes after abrasive blasting, b) resin application, c) components immediately after repair

\section{Omówienie wyników badań}

Po uprzednim napełnieniu rury olejem, podłączeniu elastycznych przewodów do hydraulicznej praski manometrycznej i odpowietrzeniu układu, rozpoczęto zwiększać ciśnienie. Pierwszą próbę wykonano dla rur wzmacnianych taśmą zbrojoną. Dla średnicy otworu $10 \mathrm{~mm}$ połączenie utraciło szczelność, przy wskazaniu manometru wynoszącym 0,02 MPa (0,2 bara). Rura z otworem o średnicy $20 \mathrm{~mm}$
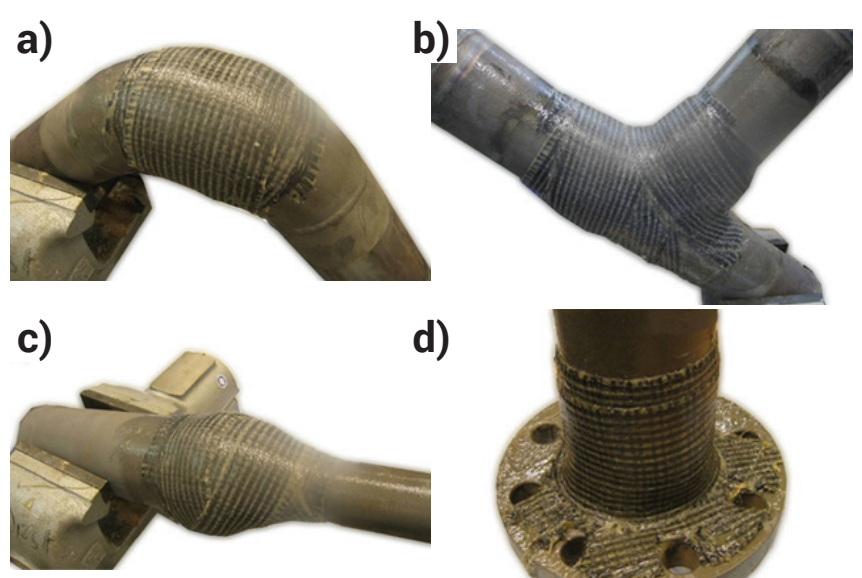

d)

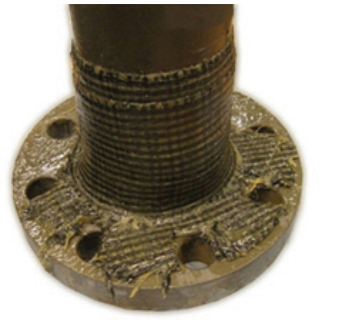

Rys. 9. Zastosowanie systemu naprawczego Loctite dla skomplikowanych geometrii instalacji: a) promień, b) trójnik, c) zbieżność średnic, d) przy kołnierzu

Fig. 9. Application of Loctite repair system for complicated geometry of installation: a) radius, d) tee, c) diameter convergence, d) flange

wykazała jeszcze mniejszą wytrzymałość, utraciła szczelność zanim wskazania manometru osiągnęło pierwszą działkę elementarną, której wartość odpowiada 0,02 MPa. W przypadku rur wzmacnianych specjalistyczną taśmą uszczelniającą wyniki były znacznie korzystniejsze. Dla elementu z otworem o średnicy $10 \mathrm{~mm}$ układ uległ rozszczelnieniu, gdy manometr wskazywał ciśnienie 0,7 MPa (7 barów). Dla rury z otworem o średnicy $20 \mathrm{~mm}$ zanotowano nieznacznie niższy wynik 0,6 MPa (6 barów). Zgodnie z oczekiwaniami największe parametry wytrzymałościowe uzyskano dla dedykowanego systemu naprawczego, dla którego rura z otworem o średnicy $10 \mathrm{~mm}$ osiągnęła ciśnienie graniczne 18,4 MPa (184 bary). Dla otworu $20 \mathrm{~mm}$ połączenie utracito szczelność, przy wskazaniu manometru wynoszącym $12 \mathrm{MPa}$ (120 barów). W tablicy 1 zestawione zostały wartości ciśnień granicznych odnotowanych podczas wykonywania doświadczeń.

Analizując wyniki pomiarów ciśnienia granicznego należy podkreślić wysokie wartości uzyskane z wykorzystaniem certyfikowanego systemu naprawczego. Rura z otworem o średnicy $20 \mathrm{~mm}$ odporna była na ciśnienie do $12 \mathrm{MPa}$, a więc $240 \%$ zakładanej wartości minimalnej. Dla próbki z otworem o średnicy $10 \mathrm{~mm}$ uzyskano aż 18,4 MPa, a więc aż $368 \%$ zakładanej wartości minimalnej. Jest to wynik bardzo dobry, który z pewnością pozwala na zastosowania tego systemu naprawczego $w$ instalacjach rurowych przemysłu petrochemicznego, dla którego był projektowany.

Tablica I. Zestawienie wyników badań Table I. Summary of research results

\begin{tabular}{|c|c|c|}
\hline \multirow{2}{*}{ materiał użyty do naprawy } & \multicolumn{2}{|c|}{ ciśnienie graniczne, MPa } \\
\cline { 2 - 3 } & $\begin{array}{c}\text { otwór } \\
\emptyset 10 \mathrm{~mm}\end{array}$ & $\begin{array}{c}\text { otwór } \\
\varnothing 20 \mathrm{~mm}\end{array}$ \\
\hline taśma zbrojonej & 0,02 & $<0,02$ \\
\hline taśma uszczelniającej & 0,7 & 0,6 \\
\hline $\begin{array}{c}\text { certyfikowany system } \\
\text { naprawczy }\end{array}$ & 18,4 & 12 \\
\hline
\end{tabular}


Dysproporcja uzyskanych wyników ciśnienia granicznego dla trzech zastosowanych rozwiązań naprawczych wynika z docelowego przeznaczenia zastosowanych materiałów. Taśma zbrojona jest materiałem uniwersalnego zastosowania i stosuje się ją jedynie do napraw doraźnych. Taśma uszczelniająca, mimo że nie jest rozwiązaniem przeznaczonym do wykonywania tego typu napraw, uzyskała bardzo dobry wynik, zachowując szczelność nawet do 0,7 MPa. Należy również podkreślić pracochłonność i czas potrzebny na wykonanie naprawy. 0 ile taśma zbrojona i uszczelniająca gwarantuje szybki proces regeneracji i 100\% wytrzymałości bezpośrednio po aplikacji, tak w przypadku rozwiązania dedykowanego czas przygotowawczy, wykonanie złącza i utwardzanie masy klejowej trwają bardzo długo.

\section{Podsumowanie}

Analiza literaturowa i badania własne pozwalają na sformułowanie stwierdzenia, iż na rynku jest dostępna szeroka gama produktów regeneracyjnych, pozwalających na przeprowadzenie napraw. Skupiając się na elementach o kształcie rurowym, szczególnie popularne są taśmy gwarantujące różną jakość łączenia - od szybkich, wygodnych w aplikacji, ogólnie dostępnych i stosunkowo niedrogich produktów doraźnych, po zaawansowane rozwiązania specjalistyczne. Przeprowadzone analizy i badania prowadzone były w oparciu o normę obejmującą wytycznymi elementy pracujące w przemyśle naftowym, petrochemicznym i gazowniczym. Z uwagi na restrykcyjne wymagania, którym sprostać mogą jedynie produkty profesjonalne, w pracy skupiono się głównie na systemie dedykowanym Loctite. Wykazuje on odporność na ciśnienia wynoszące 12 i 18,4 MPa (w zależności od średnicy otworu), przy ciśnieniu wymaganym $5 \mathrm{MPa}$, co predestynuje go do zastosowania w trudnych warunkach eksploatacyjnych. Wymaga on jednak odwzorowania szczegółowych i pracochłonnych zaleceń producenta, w zakresie przygotowania elementów i wykonawstwa operacji łączenia. Dla aplikacji mniej wymagających, producenci oferują szeroką gamę taśm naprawczych (zbrojonych i uszczelniających), które w krótkim czasie pozwalają na wykonanie naprawy doraźnej.

\section{Literatura}

[1] J. Godzimirski: Wytrzymałość doraźna konstrukcyjnych połączeń klejowych, WNT, Warszawa 2002

[2] J. Kuczmaszewski: Podstawy konstrukcyjne i technologiczne oceny wytrzymałości adhezyjnych połączeń metali, Wyd. Politechniki Lubelskiej, Lublin 1995.

[3] Z. Mirski: Klejenie materiałów, w J. Pilarczyk: Procesy spajania, Poradnik Inżyniera Spawalnika, tom II, WNT, Warszawa 2005.

[4] Z. Mirski, T. Piwowarczyk: Klejenie w budowie pojazdów samochodowych, Przegląd Spawalnictwa, nr 5-6/2004, s. 68-72.

[5] R.D. Adams, W.C. Wake: Structural adhesive joints in engineering, Elsevier Applied Science Publishers, Barking 1986.

[6] P. Jasiulek, A. Rawicz: Wpływ stanu przygotowania powierzchni metali na wytrzymałość połączeń klejonych, Przegląd Spawalnictwa, nr 7/1979, s. 11-14.
[7] J. Kuczmaszewski, J. Domińczuk: Właściwości adhezyjne warstwy wierzchniej stali konstrukcyjnych, Przegląd Mechaniczny, nr 3/2001, s. $5-8$.

[8] J. Cognard: Some recent progress in adhesion technology and science, C. R. Chimie, nr 9/2006, pp. 13-24.

[9] G.D. Davis, J.D. Venables: Surface treatments of metal adherends, in M. Chaudhury, A.V. Pocius: Adhesion Science and Engineering - 2: Surfaces, Chemistry and Applications, Elsevier Science B.V., 2002.

[10] D. Mcquillan: The structural use of adhesives, The Institution of Structural Engineers, SETO, London, 1999.

[11] G. Nowak: Materiały regeneracyjne, Materiały szkoleniowe, Instytut Maszyn i Urządzeń Energetycznych Politechniki Śląskiej w Gliwicach, Gliwice 2001 . 